\begin{tabular}{lllllll} 
& ISRA (India) & $=\mathbf{4 . 9 7 1}$ & SIS (USA) & $=\mathbf{0 . 9 1 2}$ & ICV (Poland) & $=\mathbf{6 . 6 3 0}$ \\
Impact Factor: & ISI (Dubai, UAE) $=\mathbf{0 . 8 2 9}$ & PUHЦ (Russia) $=\mathbf{0 . 1 2 6}$ & PIF (India) & $=\mathbf{1 . 9 4 0}$ \\
GIF (Australia) & $=\mathbf{0 . 5 6 4}$ & ESJI (KZ) & $=\mathbf{8 . 7 1 6}$ & IBI (India) & $\mathbf{4 . 2 6 0}$ \\
& JIF & $=\mathbf{1 . 5 0 0}$ & SJIF (Morocco) & $\mathbf{5 . 6 6 7}$ & OAJI (USA) & $\mathbf{0 . 3 5 0}$ \\
\hline
\end{tabular}

\section{SOI: $1.1 /$ TAS $\quad$ DOI: $\underline{10.15863 / T A S}$ \\ International Scientific Journal Theoretical \& Applied Science}

\author{
p-ISSN: 2308-4944 (print) e-ISSN: 2409-0085 (online) \\ Year: $2020 \quad$ Issue: 03 Volume: 83
}

Published: $30.03 .2020 \quad \underline{\text { http://T-Science.org }}$
QR - Issue

QR - Article
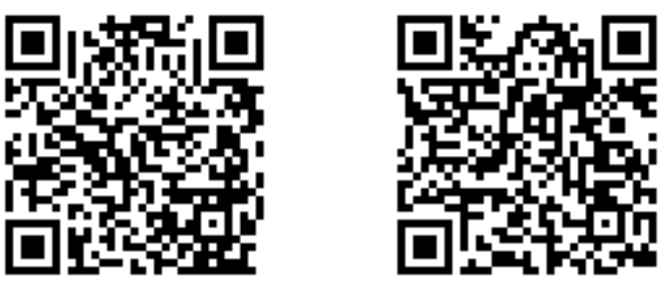

Ezekiel Evelyn Ilamosi

The Federal Polytechnic Ilaro Department of Business Administration and Management Ogun State evelyn.ezekiel@federalpolyilaro.ng

Solomon Oluyinka Baliuag University Ph.D

Research Consultant College Instructor Baliuag, Bulacan Philippines solomon467@gmail.com

\title{
ACCEPTANCE OF HUMAN RESOURCE INFORMATION TECHNOLOGY IN NIGERIA
}

\begin{abstract}
Language: English Nigeria. ISJ Theoretical \& Applied Science, 03 (83), 246-256.

Scopus ASCC: 1407.

\section{Introduction}

The use of the internet and the progression of technology has brought fundamental changes all over the world. Worldwide businesses in this information age are seeking to grow their ability to compete in the extremely competitive world market [1]. To get a relative position on the market, companies need to implement technologies. Organizational achievement depends heavily on creating new changes across all divisions of the company. Because of the rapid introduction of new technologies, information technology (IT) plays a most important role in
\end{abstract}

Abstract: This study acknowledge the variables which can influence acceptance of Human Resource technology in Nigeria. Many freelance analysis on the decisive vital factors of implementation of human resource information systems in developing countries like African nation is undertaken. This article, an effort was created parenthetically important factors that should monitored towards adoption of human resources information systems in Nigeria. Many variables were extracted from the review of literatures. Primary information was gathered through standardized questionnaires distributed to the organizations' employees. Some factors such as the organization's technology and environments are found to be most important towards acceptance of the technology mentioned by organizations. Conclusively, this particular study examines the positive effects in terms of human resources technology application in relationship to information systems on the organizational productivity.

Key words: Human resource Information systems, Economic Growth, IT, Nigeria.

Citation: Ilamosi, E. E., \& Oluyinka, S. (2020). Acceptance of human resource information technology in
Soi: http://s-o-i.org/1.1/TAS-03-83-48
Doi: crossef https://dx.doi.org/10.15863/TAS.2020.03.83.48

handling various organizational functions, especially human resource (HR).

Both the intense market and the rapid economic cycle have allowed a number of business environments, resulting in exponential growth of technology applications across all of Human Resource Management business areas. Hence, it's controlled human resource practitioners and researchers to reconsider concerning the action of organizational objectives through the adoption of integrated systems known as Human Resource Information Systems. The value of HRM is increasing with the organizational size requiring the correct generation of human 


\begin{tabular}{|c|c|c|c|c|c|c|}
\hline \multirow{4}{*}{ Impact Factor: } & ISRA (India) & $=4.971$ & SIS (USA) & $=0.912$ & ICV (Poland) & $=6.630$ \\
\hline & ISI (Dubai, UAE & $=0.829$ & РИНЦ (Russia & $=0.126$ & PIF (India) & $=1.940$ \\
\hline & GIF (Australia) & $=0.564$ & ESJI (KZ) & $=8.716$ & IBI (India) & $=4.260$ \\
\hline & JIF & $=1.500$ & SJIF (Morocce & $=5.667$ & OAJI (USA) & $=0.350$ \\
\hline
\end{tabular}

resource reports and the management of employee data pushing organizations to implement Human Resource Information Systems [2]. In general, an information system for human resources is a centralized computerized collection of human resource functions within an organization. Adoption of human resource information systems helps firm achieve the competitive edge.

In reality, it lowers the overall cost of HR activities that keep them pushing the HR program forward [3]. Data technology has changed the HR role dramatically over the last decade. Through actively assisting administrative tasks such as payroll problems, attendance management process etc. Recruitment functions embody screening, process applications, hiring or catching new staff, human resource information systems are imperative for online job advertising through company websites, online info, and electronic applicants' management.

The main position of human aid system is to retrieve and flow into relevant data regarding human sources. However, the adoption of human aid information structures within the organization is tough. At a personal level, there's a defense of private interests and values. The area unit may influence the mixing of such innovation at the structural level. To boost structure effectiveness and productivity, innovations ought to be adopted and incorporated; so, human resource managers adhere to the adoption of human resource information systems.

The presentation of human asset data frameworks has been relied upon to empower a productive and vital heading to work with HR professionals [4]. Utilizing human asset data frameworks is the technique for making the usage of HR methodologies and arrangements to improve performance. This helps time unit operations to fulfill organization desires through technology human resource information systems offer a platform that permits users as well as directors, staff, and time unit practitioners to vary information, increasing the organizations' machine-controlled coverage necessities. Intent organizations are likely to embrace newer technology may relies on existing technology forbearance and departmental associates [4]. Based on this issue, organizations often face difficulties when it comes to implementing information systems for human resources.

In a nutshell, human resource information systems should not be seen as expenses but have to be compelled to be viewed as investments [5]. To boot, expenses incurred in building the infrastructure for finalizing or mercantilism knowledge systems for the human resources unit of measurement substantial in money terms. Its place along true that the return generated from this investment over the long quantity of sometime is else necessary and profitable. In fact, the relative profit at the aspect of the malleability is totally correlate with the organization's adoption of human resource information systems [6].

1.1 Objective of the study

This paper aims to explore the follow concerns: a) to determine factors influencing organizations adopting human resource information systems in Nigeria and b) to observe the overall representation of human resource information systems factor through structural modelling equation analyze to contribute strong evidences.

\section{Related Literatures}

The HRM area can be characterized as having experienced the visit and various innovation developments. Some of the terms provide the human asset information structure (human asset data frameworks), electronic human asset management (eHRM) and virtual human asset management [7]. A human resource information system is a system used to collect, store, manage, evaluate, retrieve, and distribute relevant information about the human resources of an entity and after evaluating the many meanings of information systems for human resources. Kavanagh, Gueutal \&Tannenbaum [8] characterized it as a framework utilized to procure, store, control, analyze, recover, and convey data with respect to an organization's human assets.

Essentially, human asset data frameworks are the mix of human asset administration and data innovation [9]. It is the combination of database, equipment, and computer program that is used to store information from all divisions of the organization within the database and deliver the desired data to skill personnel on request [10]. The business world has been blended by the approach of IT, data frameworks, and web innovation [11]. Researchers also emphasized the assumption that technology offers opportunities for organizations to evolve and helping them achieve comparative advantages [12].

In current information economy, organizational success is subordinate on proficiency of human assets [13]. It is opined that IT ought to play imperative part in Human Asset Administration (HRM) space [14]. It was further asserted that the use of appropriate application of Information Technology (IT) in HRM is a successful way to run business in today's world [15]. Organizational variables reflect the organization's attributes that affect the company's implementation of human resource information systems [16] expressed that for fruitful development selection, organization estimate, best level administration back and gifted workforce are considered as vital variables.

About the technology aspect, [17] reported that it focuses on the characteristics of the technology that may affect the organization's enactment of human resource information systems, [18] claimed that the benefits that organizations seek to gain from adoption include quality of service rates, performance and 


\begin{tabular}{|c|c|c|c|c|c|c|}
\hline \multirow{4}{*}{ Impact Factor: } & ISRA (India) & $=4.971$ & SIS (USA) & $=0.912$ & ICV (Poland) & $=6.630$ \\
\hline & ISI (Dubai, UAE & $=0.829$ & РИНЦ (Russia & $=0.126$ & PIF (India) & $=1.940$ \\
\hline & GIF (Australia) & $=0.564$ & ESJI (KZ) & $=8.716$ & IBI (India) & $=4.260$ \\
\hline & JIF & $=1.500$ & SJIF (Morocce & $=5.667$ & OAJI (USA) & $=0.350$ \\
\hline
\end{tabular}

reliability. Conversely, there are some obstacles to the implementation of human resource information systems, such as complexity in creativity, difficulty in compliance with the operational competency structure, acceptance of human resource info systems by staff or users; compatibility was described as the extent of steady purporting of innovation, including the current valuations and previous experiences needed by likely users [19].

Stroh and Caligiuri [20] expressed that organizations are realizing that they will be incapable to form them competitive unless they oversee their human assets successfully. These insisted on the organizations ' atmosphere where they perform their trade operations. Some of the natural components include industry highlights, government rules and controls as well as frameworks which have a colossal effect on the appropriation of human resource data frameworks. Success and disappointment of the selection depends on specified components [18]. After the selection it is required to prepare the clients or representatives so that they can effortlessly utilize the framework and bring the effectiveness within the business operation.

The literature indicates a variation in the study of the use of human resource information systems with at least two use peaks [21]. In this context, [22] and [23] argue that it is possible to use human resource information systems for administrative purposes which reduce costs and time and support more analytical decision making. Lippert and Swiercz [13] distinguished distinctive sort of human asset data frameworks utilizations based on degree of advancement. The study described the management of payroll and benefits, maintaining employee and absence records electronically as unsophisticated use of human resource information systems; he describes this as simple-minded automation, too.

Further, Lippert and Swiercz [13] described the use of human resource information systems in recruiting and selection, training and development (T\&D), HR preparation and performance evaluation as sophisticated, as the information produced is relevant and used to support important HRM decisions. Bredin and Söderlund [24] advocated that there's importance with respect to the human asset data frameworks execution and it shifts from organization to organization. A few organizations utilize human asset data frameworks in arrange to decrease fetched, a few utilize to bring speeding up in communication, a few may utilize the framework to re-orient HR exercises to improve an increment the key choice of the office. In this manner, the human resource information frameworks application can minimize the HR related cost since computerization within the HR handle makes a difference to reduce number of representatives within the firms and encourage the checking and controlling data. It also helps managers to access relevant information to help them interpret facts, make faster decisions, and interact with necessity-based people [25].

APEC [26] expressed that E-Readiness is the point at which a community plans themselves in arrange to lock in within the computerized economy stage. Quantifying E-readiness relies on the assessment of both the company's incredible opportunities and difficulties. With respect to creating nations like Nigeria, firm's e-Readiness evaluation can be supportive to set up rudimentary benchmarks for inside comparison by representatives and their degree of intrigued in computerized stage presentation. At the same time, it is additionally genuine that different e-Readiness evaluation models may shift in terms of goals and strategies as well as results.

The Information Systems Division plays a significant role in supporting the computerization of the HR division in both the planning and development phases of the implementation of human resource information systems. To achieve the productivity of human resource information systems, workers must be equipped with computer training relating to that of the HR role. It has been found that one of the major issues with respect to HR administration is the need for specialized preparing for data administration [27]. In addition, adequate training must be given to all workers, from line managers to operational staff. For the full implementation of human resource information systems, the provision of technical experts is necessary and the successful implementation of human resource information systems is highly dependent on human resource availability.

Based on the organizational progression, the number of workers, offices and branches over the organization is considered as a fundamental figure with respect to the usage of human asset data frameworks particularly in LAN innovation. Lai and Guynes [28] contended that there's no major relationship between the coordinates administrations computerized arrange execution as well as the level of centralization and complexity nature. Lipnack and Stamps [29] inferred that the organizational structure remained fractured in the case of intranet diffusion or infusion means internet connectivity within the organization. Human asset data frameworks improvement and execution in Nigeria is gone through from numerous issues. It is since the HR representatives directorates wrap up through exceed expectations at program. So they don't pick up any benefits determined from human asset data frameworks. In comparison, Noe, Hollenbeck, Gerhart and Wright [30] reported that they have positive effects on learning materials for human resource information systems. IT infrastructure makes a positive contribution to the successful implementation of human resource information systems. It includes excellently-configured computer 


\begin{tabular}{|c|c|c|c|c|c|c|}
\hline \multirow{4}{*}{ Impact Factor: } & ISRA (India) & $=4.971$ & SIS (USA) & $=0.912$ & ICV (Poland) & $=6.630$ \\
\hline & ISI (Dubai, UAE & $=0.829$ & РИНЦ (Russia & $=0.126$ & PIF (India) & $=1.940$ \\
\hline & GIF (Australia) & $=0.564$ & ESJI (KZ) & $=8.716$ & IBI (India) & $=4.260$ \\
\hline & JIF & $=1.500$ & SJIF (Morocce & $=5.667$ & OAJI (USA) & $=0.350$ \\
\hline
\end{tabular}

frameworks and exceedingly strong information bases that improve as well as assemble data and store information and give the fitting and fitting prepare of data.

Agreeing to the Fink and Neumann [31] foundation is basic achievement figure seeing commerce esteem of the firm. It depends on the level of information with the development and relate handle [32], [33]. The technology may function as interagency HR-related activities and these can be combined to adopter sectors. Kumar [19] suggested that there are two aspects to compatibility; one is the values of the adopter and the other is the adopter practices. Adopters' values relate to the cognitive compatibility and adopters' hones relate to the down to earth and operational movement and compatibility [34].

On the other hand, the company's financial capability is much more important in addition to the top management support. The reason for this is that the company's top management has agreed or shown interest in implementing human resource information systems in the company but there will be no fruitful outcomes if they do not have adequate money or investment capability. The primary goal of applying in a firm is to achieve competitive advantage from the market so that competitors reside outside the limitations of human resource information systems. Companies that have already adopted human resource information systems are in a competitive position, and will gain long-term outcomes from the implementation of human resource information systems.

Frambach and Schillewaert [35] said several empirical studies indicate that economic pressure is seen as an important factor for both IT adoption and diffusion. Meanwhile, as organizations move into a knowledge-based economy, the elevations are constantly growing to reduce long-term HR costs as well as satisfy a tactical role within the organization. To support or defend the adoption of innovation, the organizational structure should be narrated. It can be disclosed by a few parameters just like the level of centralization inside the firm and the degree of worker specialization inside the firm as well as formalization of different exercises interior the firm. In the aforementioned parameters, the extent of employee specialization is considered a strong ingredient or criteria in the implementation of technology in an organization, in particular human resource information systems.

Top management assistance is one of the essential segments for successful delivery of the human resource information systems. The process of implementing human resource information systems would fail if they don't give their consent. It is observed that when Information System is to be introduced in the organization, many managers always want gradual improvement factors related to execution of operations, increase of efficiency, distribution of time service, etc. [36]. In general, toplevel management shows a lack of interest in IS incorporation such as human resource information systems. Management at the top level feels spending time and investing money would seem pointless. They sometimes want to gain short-term benefits along with this concept, which is not possible, but they need to consider long tern benefits. According to Gordon and Monideepa [37], top-level management support is considered to have a positive impact on the adoption of human resource information systems in relation to methods and competencies.

Organizational behavior scholars have said there is a positive relationship between the success of an organization and its culture. Successful firms, along with the management process, have the potential and power to embrace and implement technological innovation in their culture. Doz [38] claimed that corporate culture is at the heart of the innovation of the company's organization. Jackson [39] discussed that in the situation of success and failure of the IS adoption, organizational culture must be considered as a critical factor.

\subsection{Functional Modules of Human Resource Information Systems}

Human resource information systems roles were developed to allow the information system to take the techniques and strategies used to manage the human capital of the organization and the procedures needed to enable both the hardware and software applications of the computer [40] According to Boating [41] other key roles of human resource information systems include: incorporation of human resource information systems technologies, greater productivity than before, greater efficiency. It-enabled processes must be given priority as information technology affects human resources practices [42]. The management of human resource information systems involves a distinct supporting role within HR department. It can certainly be said that human resource information systems ' operational systems are the life blood for the business and the businesses that have implemented the system have started to benefit.

\subsection{Essentialities of Human Resource Information Systems}

Business can easily track labor shortages, labor quantity and quality, discuss future employment meeting business HR requirements through the HR information management systems [43]. Meanwhile, a human resource information system maintains the range of workforce planning with correct information and ensures the preparation of supply and demand. In addition to these opportunities, human resource information systems could be used to assist workers with equal employment opportunities, differentiate candidate credentials, improve training programs and 


\begin{tabular}{|c|c|c|c|c|c|c|}
\hline \multirow{4}{*}{ Impact Factor: } & ISRA (India) & $=4.971$ & SIS (USA) & $=0.912$ & ICV (Poland) & $=6.630$ \\
\hline & ISI (Dubai, UAE & $=0.829$ & РИНЦ (Russia & $=0.126$ & PIF (India) & $=1.940$ \\
\hline & GIF (Australia) & $=0.564$ & ESJI (KZ) & $=8.716$ & IBI (India) & $=4.260$ \\
\hline & JIF & $=1.500$ & SJIF (Morocce & $=5.667$ & OAJI (USA) & $=0.350$ \\
\hline
\end{tabular}

correct budget planning as well as to maintain employee-labor relationships [42].

\subsection{Challenges in Implementing Human} Resource Information Systems

According to Kovach and Cathcart [22], there were major obstacles to achieving maximum potential: inadequate funds and lack of top management support. Furthermore, they stated that major barriers indicate insufficient human resource knowledge processes for designers and due to this lack of knowledge; it is difficult for designers to provide adequate problem solutions. The institute of management and administration carried out a survey in 2002 on the major obstacles to managing human resource information systems. The obstacles they included in the survey questionnaire included: lack of staff, inadequate budget, and lack of it support, poor time management, and need for cooperation with other departments [44]. If firms think they have a competitive edge, they can be willing to adapt the new technology. Nonetheless, many organizations resist the development of new technology such as human resource information systems, unless there are perceptible benefits.

One explanation for reluctance to adopt and incorporate human resource information systems is that massive funds are needed [45]. The big hurdle in the introduction of human resource information systems is said to be the huge cost of setting up and maintaining a human resource information systems [46]. The infrastructure costs along with the software packages are high and the maintenance costs are high for implementing human resource information systems. Furthermore, the provision of personal computers to staff and internet access is important to leverage on all HR possibilities. The transitional costs from traditional HR to a human resource information system were found to be high [47].

In addition, the costs of hardware and software are important along with the maintenance costs. As it is stated, human resource information systems functions as interdepartmental HR-related activities and these can be matched to adopter sectors. However, compatibility is another issue in which companies cannot make the implementation successful unless technology is compatible with the company's existing framework or infrastructure.

\section{Material and Research Methods}

The purpose of this analysis is descriptive and the qualitative as well as quantitative data were used for the study. Quantitative data were collected from primary source by conducting surveys, and qualitative data were collected by secondary data sources such as the Internet, articles, books, etc.

For this study, the population comprised all those organizations that adopted human resource information systems innovation operating in Nigeria and were in the process of implementing or implementing innovation. The survey was conducted using standardized questionnaires that incorporate assumptions from the 5-point Likert scale [48]. A random sample of 150 employees was asked to fill out the structured questionnaire, comprised of 15 out of 10 organizations. The participants were 65 percent male and 35 percent female. The majority of participants were young (aged 25-40) with high background in education. Analysis of the exploratory factor was carried out to decide if multiple variables form one aspect of factor. Structured equation modeling was then conducted to describe the relationship between factors and variables. The study was carried out using statistical software SPSS 22.0 and SmartPLS.

\subsection{Conceptual Framework and Hypothesis}

In Nigeria, attempts have been made to find out the factors affecting the adoption of human resource information systems. The conceptual and hypothetical framework presented in the figure 1 .

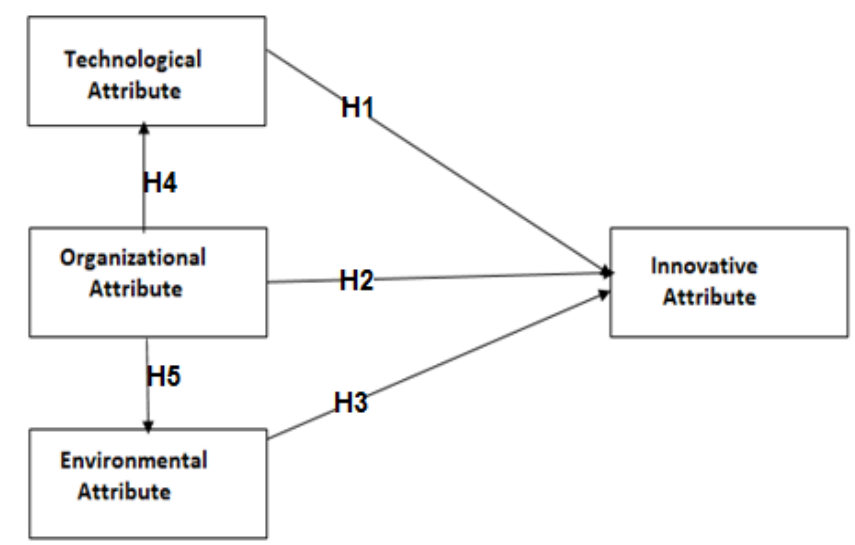

Figure 1: Hypothetical Conceptual Framework 


\begin{tabular}{|c|c|c|c|c|c|c|}
\hline \multirow{4}{*}{ Impact Factor: } & ISRA (India) & $=4.971$ & SIS (USA) & $=0.912$ & ICV (Poland) & $=6.630$ \\
\hline & ISI (Dubai, UAE & $=0.829$ & РИНЦ (Russia & $=0.126$ & PIF (India) & $=1.940$ \\
\hline & GIF (Australia) & $=0.564$ & ESJI (KZ) & $=8.716$ & IBI (India) & $=4.260$ \\
\hline & JIF & $=1.500$ & SJIF (Morocce & $=5.667$ & OAJI (USA) & $=0.350$ \\
\hline
\end{tabular}

\subsubsection{Hypothesis}

Considering the literature reviewed this study suggested the following hypotheses towards identifying attributes to human resource technology acceptance in Nigeria Organization. Thus, H1: Technological attributes about influences the innovative attributes to accept the technology. H2: Organizational attribute may have influence the innovative attributes to accept the technology and $\mathrm{H} 3$ : Environmental attributes may have influence the innovative attributes to accept the technology.

This particular study also investigates whether there is relationship among the suggested attributes to accept the technology. Therefore, H4: there is relationship between organizational attribute and technological attribute to accept the technology, and H5: there is relationship between organizational attribute and Environmental attribute to accept the technology

\section{Method of study}

Human resources officials and employee from different organizations within Nigeria, the number of people interviewed in this current study justified based on previous studies [49], [50]. This is a structural equation modeling that based on factor scores prediction. The R-squares and p-value of 0.05 adopted to justify the significance of the attributes.

\subsection{The instrument adopted}

The implemented tools based on the publications surrounded by two decades that related to social science studies and technology management in the human management. Although, some reviewed theories established within the range of 1986 to 2000 like IDT [51, TAM [52] to build the foundation and improvement of the questionnaire to support reliable findings of this study.

A set of questionnaire sections developed based on the technology theories reviewed and hypothesized queries related technological attributes, innovative attributes to accept the technology. Also, organizational attribute and environmental attributes to accept the technology in the context of Nigeria asked. A 5-Likert scale response table provided for the developed instrument.

The population comprised all those organizations that adopted human resource information systems innovation operating in Nigeria and were in the process of implementing or implementing innovation.

A random sample of 140 employees considered as the unit of analysis [53]. The employees were asked to fill out the structured questionnaire, comprised of 5 organizations. The participants were 63 percent male and 37 percent female. The majority of participants were young (aged 20-45) with minimum senior secondary school certificates and above in term of education.

Analysis of the exploratory factor was carried out to decide if multiple variables form one aspect of factor. Variance structured equation modeling was then conducted to describe the relationship between independents and dependents suggested attributes. The study was carried out using statistical tool SPSS 22.0

\section{Data Analysis and Findings}

This part deals with test hypotheses. The hypotheses have been tested using chi-squared (R2) test in order to determine whether there is an impact of independent variables on acceptance of human resource information systems. The significance of this study justified based the Decision rules attributes: if resultant value is greater than critical value and " 0.05 " level of significance has been used to analyze the collected data and support the findings, which is test (probability value) yields significant results.

However, factor analysis conducted to minimize and determine useful number of total variables. The statistic Bartlett's test of Sphericity used along with the Kaiser-Meyer-Olkin (KMO) statistic shows small values (below 0.5) to support the correlations between pairs of variables justification, also noted 0.829 (Table 1) which is very much strong to continue a factor analysis.

\section{Table 1: KMO and Bartlett's Test}

\begin{tabular}{|l|l|l|}
\hline Kaiser-Meyer-Olkin Measure of Sampling Adequacy. & .829 \\
\hline \multirow{3}{*}{ Bartlett's Check } & Approx. Chi-Square & 19727.9 \\
\cline { 2 - 3 } & Df & 2780 \\
\cline { 2 - 3 } & Sig. & .000 \\
\hline
\end{tabular}

The 16 variables divided by four attributes such as organizational, technological, environmental and innovative attributes that practice human resource information systems and the relationship between the attribute. Firstly, the values shown in table 1 above 0.5 indicate a rational factorability. Secondly, the sampling adequacy score for Kaiser-Meyer-Olkin was approximately 83 percent above the recommended value of 0.6.

Finally, an overall indicator usable was 16 items, after factor analysis. The axis factoring was used because the primary purpose was to identify and calculate composite coping scores for the short version considerations. 


\begin{tabular}{|c|c|c|c|c|c|c|}
\hline \multirow{4}{*}{ Impact Factor: } & ISRA (India) & $=4.971$ & SIS (USA) & $=0.912$ & ICV (Poland) & $=6.630$ \\
\hline & ISI (Dubai, UAE & $=0.829$ & РИНЦ (Russia & $=0.126$ & PIF (India) & $=1.940$ \\
\hline & GIF (Australia) & $=0.564$ & ESJI (KZ) & $=8.716$ & IBI (India) & $=4.260$ \\
\hline & JIF & $=1.500$ & SJIF (Morocce & $=5.667$ & OAJI (USA) & $=0.350$ \\
\hline
\end{tabular}

The initial values showed that 42.84 percent of the variance explained was justified by the fourth attributes. The variance reported based both varmax rotations and the factor loading matrix.

\subsection{Exploratory Factor Analysis}

An exploratory examination was conducted with the adoption of SPSS 22.0, reports included discriminant validity

\subsubsection{Factor Loadings}

Table 2 shows the rotated factor matrix resulting from a varmax rotated principle axis factor requiring independent variables using the 1.0 separate value cutoff criterion, which indicates that the four factors have emerged and report their factor loading. All factor cross loadings justified acceptable for further study.

Table 2: Cross factors loadings justified

\begin{tabular}{|l|l|l|l|l|}
\hline \multicolumn{9}{|l|}{} \\
\hline CODES & ENVIRONMENTAL & INNOVATIVE & ORGANIZATION & TECHNOLOGICAL \\
\hline ENV1 & 0.759 & 0.359 & 0.423 & 0.294 \\
\hline ENV2 & 0.851 & 0.515 & 0.404 & 0.449 \\
\hline ENV3 & 0.740 & 0.390 & 0.355 & 0.245 \\
\hline ENV4 & 0.728 & 0.502 & 0.369 & 0.355 \\
\hline INN1 & 0.421 & 0.689 & 0.414 & 0.563 \\
\hline INN2 & 0.436 & 0.779 & 0.430 & 0.521 \\
\hline INN3 & 0.482 & 0.816 & 0.575 & 0.538 \\
\hline INN5 & 0.440 & 0.759 & 0.518 & 0.426 \\
\hline ORG1 & 0.374 & 0.481 & 0.702 & 0.391 \\
\hline ORG2 & 0.407 & 0.421 & 0.712 & 0.336 \\
\hline ORG4 & 0.356 & 0.529 & 0.855 & 0.435 \\
\hline ORG5 & 0.453 & 0.578 & 0.885 & 0.455 \\
\hline TEC1 & 0.282 & 0.451 & 0.415 & 0.692 \\
\hline TEC2 & 0.328 & 0.558 & 0.342 & 0.824 \\
\hline TEC3 & 0.387 & 0.484 & 0.399 & 0.701 \\
\hline
\end{tabular}

5.1. 2: Reliability Analysis

All factor loadings were greater than 0.6 suggesting an appropriate significant validity point [54], [55]. Justification reported in table 3 of this study. The data were examined using the SPSS reliability analysis to evaluate the Cronbach's alpha. All evaluated above 0.7 required in most cases and as suggested in studies [56], [57].

Details reported in table 3 of this study

Table 3: Cronbach's Alpha

\begin{tabular}{|l|l|}
\hline CONSTRUCTS & SUPPORTED CRONBACH REPORTED \\
\hline Environmental & 0.773 \\
\hline Innovative & 0.798 \\
\hline Organization & 0.799 \\
\hline Technological & 0.787 \\
\hline
\end{tabular}

\subsubsection{Discriminant validity}

The study took a step involved in validity of the instrument to ensure rigor and accuracy on the research instruments and measurement models. Discriminant assumptions with SPSS properties performed. The discriminant justified and reported based on test of equality of mean, pooled within group matrices and Wilks' Lambda reports. Details in data analysis section of this study. The assumption considered on 127 cases which suggest deletion of 13 cases from the total of 140 cases. Table 4 Tests of Equality of Group Means and Pooled within Groups Matrices justified the significance of the instruments. 


\begin{tabular}{|c|c|c|c|c|c|c|}
\hline \multirow{4}{*}{ Impact Factor: } & ISRA (India) & $=4.971$ & SIS (USA) & $=0.912$ & ICV (Poland) & $=6.630$ \\
\hline & ISI (Dubai, UAE & $=0.829$ & РИНЦ (Russia & $=0.126$ & PIF (India) & $=1.940$ \\
\hline & GIF (Australia) & $=0.564$ & ESJI (KZ) & $=8.716$ & IBI (India) & $=4.260$ \\
\hline & JIF & $=1.500$ & SJIF (Morocce & $=5.667$ & OAJI (USA) & $=0.350$ \\
\hline
\end{tabular}

Table 4: Tests of Equality of Group Means and Pooled within Groups Matrices

\begin{tabular}{|l|l|l|l|l|l|}
\hline Tests of Equality of Group Means and Pooled & Wilks' Lambda & $F$ & $d f 1$ & $d f 2$ & Sig. \\
\hline Attributes & 0.75 & 107.83 & 1.00 & 125.00 & 0.00 \\
\hline Environmental & 0.96 & 13.39 & 1.00 & 125.00 & 0.00 \\
\hline Innovative & 0.81 & 76.36 & 1.00 & 125.00 & 0.00 \\
\hline Organization & 0.88 & 43.05 & 1.00 & 125.00 & 0.00 \\
\hline Technological & & & & & \\
\hline
\end{tabular}

\begin{tabular}{|c|c|c|c|c|c|}
\hline \multicolumn{6}{|c|}{ Pooled Within-Groups Matrices } \\
\hline \multirow{5}{*}{ 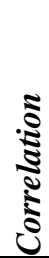 } & Attributes & Environmental & Innovative & Organization & $\begin{array}{l}\text { Technologica } \\
1\end{array}$ \\
\hline & Environmental & 1.00 & .73 & .70 & .68 \\
\hline & Innovative & .73 & 1.00 & .66 & .64 \\
\hline & Organization & .70 & .66 & 1.00 & .55 \\
\hline & Technological & .68 & .64 & .55 & 1.00 \\
\hline
\end{tabular}

\section{6.1 Components relationship} structural modeling

AMOS properties adopted to examine the relationship between attributes to accept Human Resources Information system Nigeria Organizations [58] . This justify objective one of this study (i.e., H1, $\mathrm{H} 2$, and $\mathrm{H} 3$ ). On the other hand, $\mathrm{H} 4$ organization regressed on technological and H5: organization regressed on the environmental. Figure 2 reported the significant relationship among environmental, Organization and Technological as (independent factors), and Innovative attribute positioned as (dependent factor). The modeling and fitness shall be justified with $P$ value: significant at $p<0.05$; and Squared multiple correlations (variance explained)

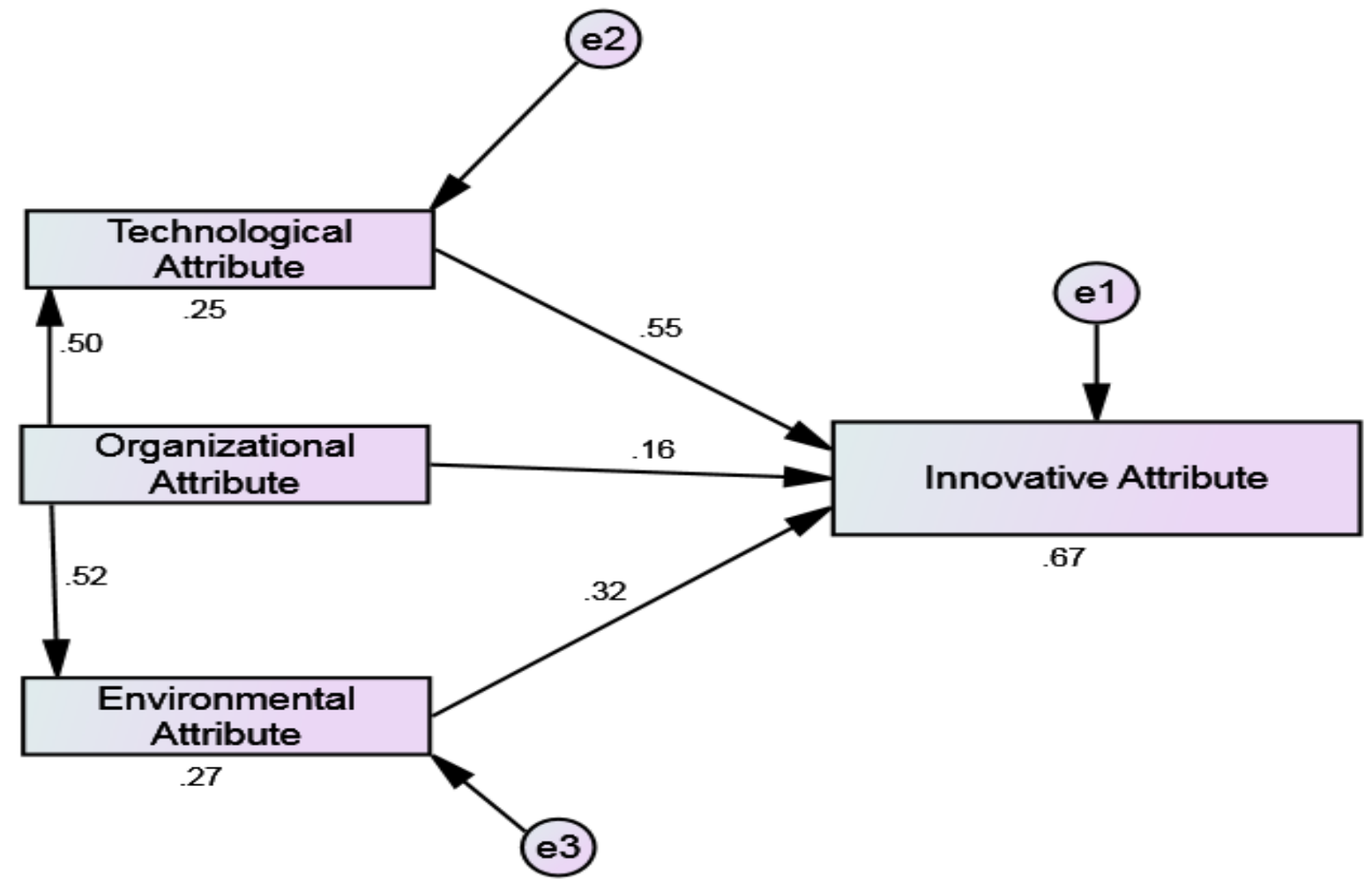

Figure 2 reported the significant relationship among environmental, Organization and Technological as (independent factors), and Innovative attribute 


\begin{tabular}{|c|c|c|c|c|c|c|}
\hline \multirow{4}{*}{ Impact Factor: } & ISRA (India) & $=4.971$ & SIS (USA) & $=0.912$ & ICV (Poland) & $=6.630$ \\
\hline & ISI (Dubai, UAE & $=0.829$ & РИНЦ (Russia & $=0.126$ & PIF (India) & $=1.940$ \\
\hline & GIF (Australia) & $=0.564$ & ESJI (KZ) & $=8.716$ & IBI (India) & $=4.260$ \\
\hline & JIF & $=1.500$ & SJIF (Morocce & $=5.667$ & OAJI (USA) & $=0.350$ \\
\hline
\end{tabular}

As expected, technological attributes $\beta=0.55, \mathrm{p}$ $<0.000$, organizational attribute $\beta=0.16, p<0.002$, and environmental attributes $\beta=0.32, \mathrm{p}<0.000$ suggested having direct impact on innovative attribute to accept Human resource information system in Nigeria. Likely, organizational attribute regressed on technological attribute $\beta=0.50, \mathrm{p}<0.000$ and organizational attribute regressed on environmental attribute $\beta=0.52, p<0.000$ also justified significant relationship towards innovative attributes. Conclusively variance explained showed 67 percent (R2). Finally, summary of the findings indicated in table 5 of this study

Table 5: Summary of Findings

\begin{tabular}{|l|l|l|l|l|l|l|l|}
\hline \multicolumn{2}{|l|}{ Regression Weights: (Group number 1 - Default model) } \\
\hline Dimensions & Estimate & S.E. & C.R. & P & $\begin{array}{l}\text { Support } \\
\text { ed? }\end{array}$ \\
\hline Environmental & $<---$ & Organizational & 0.521 & 0.059 & 8.810 & $* * *$ & Yes \\
\hline Technological & $<---$ & Organizational & 0.496 & 0.060 & 8.239 & $* * *$ & Yes \\
\hline Innovative & $<--$ & Technological & 0.528 & 0.044 & 12.111 & $* * *$ & Yes \\
\hline Innovative & $<---$ & Organizational & 0.151 & 0.049 & 3.058 & 0.002 & Yes \\
\hline Innovative & $<---$ & Environmental & 0.310 & 0.044 & 6.979 & $* * *$ & Yes \\
\hline
\end{tabular}

\section{Conclusion\& Recommendation}

It is therefore clear that human resource information systems supports planning, administration, decision-making and control and thus facilitates applications such as selection of employees, placement of employees, payroll management, pension management, training projections and performance evaluation. These information systems enhance administrative efficiency and generate reports which can improve decision-making. Technology and environment affect the successful adoption of human resource information systems. On the other hand, in the sense of the positive implementation of human resource information systems, the organizational element does not have any successful impact on both technology and environment.

Organization can set up human resource information systems with high network externalities to improve service delivery and improve the performance level of day-to-day work that will help reduce the operating human resource department costs and also increase the efficiency and effectiveness of the human resource department. organizations should perhaps pay close attention to developing trained and skilled it teams and organizations should plan automated performance indicators that allow them to engage step by step with human resource information systems as a starting point for the effective implementation of human resource information systems by the skills of their employee.

\section{References:}

1. Hitt, J. Wu, \& X. Zhou (2002), "Investment in Enterprise Resource Planning: Business Impact and Productivity Mea- sures," Journal of Management Information Systems, Vol. 19, No. 1, pp. 71-98.

2. Warui, C. M. (2016). Determinants of human resource information systems usage in the teachers service commission's operations in Kenya (Doctoral dissertation, COHRED, JKUAT).

3. Marler, J. H., \& Fisher, S. L. (2016). Making HR Technology Decisions: A Strategic Perspective. Business Expert Press.
4. Gardner, S. D., Lepak, D. P., \& Bartol, K. M. (2003). Virtual HR: The impact of information technology on the human resource professionals "e, Journal of Vocational Behavior, vol. 63, pp. 159-179.

5. Holz, P. (2018). Towards A New Social Order? Real Democracy, Sustainability \& Peace. Vernon Press.

6. Raza Syed Hassan R, Syeda Qudsia Batool, \& Dr. M.A Sajid. (2012). Benefits and Barriers of Human Resource Information System In Accounts Office \& Azad Jammu \& Kashmir Community Development Program. 


\begin{tabular}{|c|c|c|c|c|c|c|}
\hline \multirow{4}{*}{ Impact Factor: } & ISRA (India) & $=4.971$ & SIS (USA) & $=0.912$ & ICV (Poland) & $=6.630$ \\
\hline & ISI (Dubai, UAE & $=0.829$ & РИНЦ (Russia & $=0.126$ & PIF (India) & $=1.940$ \\
\hline & GIF (Australia) & $=0.564$ & ESJI (KZ) & $=8.716$ & IBI (India) & $=4.260$ \\
\hline & JIF & $=1.500$ & SJIF (Morocce & $=5.667$ & OAJI (USA) & $=0.350$ \\
\hline
\end{tabular}

International Journal of Humanities and Social Science, 2(3).

7. Ngai, E. W. T., Law, C. C. H., \& Wat, F. K. T. (2008). Importance of the Internet to Human Resource Practitioners in Hong Kong.Personnel Review, 37(1), 66-84.

8. Kavanagh, Gueutal, \& Tannenbaum (1990). Kavanagh, M. J., Gueutal, H. G., \&Tannenbaum, S. I. (1990). Human resource information systems. Boston: PWS-Kent.

9. DeSanctis, G. (1986). Human resource information systems: A current assessment. MIS Quarterly, March, 15-27.

10. Broderick, R., \& Boudreau, J. (1992). Human resource management information technology and the competitive edge. Academy of Management Executive, 6(2), 7-17.

11. Damanpour, F., \& Schneider, M. (2006). Phases of the adoption of innovation in organizations: effects of environment, organization and top managers 1. British journal of Management, 17(3), 215-236.

12. Culnan, M., \& Markus, M. (1987). Information Technologies in History of Organizational Communication. Sage, 420-443.

13. Lippert, S., \& Swiercz, P. (2005). Human resource information systems (HUMAN RESOURCE INFORMATION SYSTEMS ) and technology trust. Journal of Information Science, 31(5), 340-353.

14. Chandna, P., \& Krishnan, V. R. (2009). Organizational commitment of information technology professionals: Role of transformational leadership and work-related beliefs. Tecnia Journal of Management Studies, 4(1), 1-13.

15. Zhang, L., \& Wang, H. (2006). Intelligent information processing in human resource management: an implementation case in China. Expert Systems, 23(5), 356-369.

16. Kell, H. J., \& Lang, J. W. (2017). Specific abilities in the workplace: More important than $\mathrm{g}$ ?. Journal of Intelligence, 5(2), 13.

17. Orlikowski, W. J., \& Robey, D. (1991). Information technology and the structuring of organizations. Information systems research, 2(2), 143-169.

18. Oliveira, T., \& Martins, M. F. (2010). Understanding e-business adoption across industries in European countries. Industrial Management \& Data Systems, 110(9), 13371354

19. Kumar, R. (2010). Human resource management: Strategic analysis text and cases. IK International Pvt Ltd.

20. Stroh, L. K., \& Caligiuri, P. M. (1998). Increasing global competitiveness through effective people management. Journal of World Business, 33(1), 1-16.
21. Ball, K. S. (2001). The use of human resource information systems: A survey. Personnel Review , 30(6), 677-693.

22. Kovach, K.A., \& Cathcart, C.E. (1999). Human resource information systems (HUMAN RESOURCE INFORMATION SYSTEMS ): providing business with rapid data access, information exchange and strategic advantage. Public Personnel Management, 28, 275-281

23. Kovach, K.A., Hughes, A.A., Fagan, P., \& Maggitti, P.G. (2002). Administrative and strategic advantages of HUMAN RESOURCE INFORMATION SYSTEMS. Employment Relations Today, 29, 43-8.

24. Bredin, K., \& Söderlund, J. (2011). Human resource management in project-based organizations: The HR quadriad framework. Springer.

25. Awazu, Y., \& Desouza, K. C. (2003). "Knowledge Management", HR Magazine, 48(11), 107.

26. APEC (2000). Asian Pacific Economic Cooperation (2000), "E-Commerce Readiness Guide, Electronic Commerce Steering Group", (APEC), Retrieved from www.ecommerce.gov/apec, 2000.

27. Denton, K. D. (1987). Getting the technology up and running: An experience at Litton: Advanced circuitry division, IE, Jan-Feb, 20-12.

28. Lai, V. S., \& Guynes, J. L. (1997). An assessmentof the influence of organizational characteristics oninformation technology adoption decision: A discriminativeapproach. Engineering Management, IEEE Transactionson, 44(2), 146-157

29. Lipnack, J., \& Stamps, J. (1997). Virtual teams: Reaching across space, time, and organizations with technology. Jeffrey stamps.

30. Noe, R. A., Hollenbeck, J. R., Gerhart, B., \& Wright, P. M. (2015). Human resource management. Gaining a Competitive.

31. Fink, \& Seev, N. (2009). "Exploring the Perceived Business Value of the Flexibility Enabled by Information Tech- nology Infrastructure," Information \& Management, Vol. 46, No. 2, pp. 90-99.

32. Cretchley, P. (2007). Does computer confidence relate to levels of achievement in ICT-enriched learning models?. Education and Information Technologies, 12(1), 29-39.

33. Duxbury, L., \& Corbett, N. (1996). Adoption of portable offices: An exploratory analysis. Journal of Organizational Computing and Electronic Commerce, 6(4), 345-363.

34. Kim, D. (2009). Adoption of personal information system: Innovation diffusion theory and task-technology fit. Academy of Information and Management Sciences, 13(2), 50. 


\begin{tabular}{|c|c|c|c|c|c|c|}
\hline \multirow{4}{*}{ Impact Factor: } & ISRA (India) & $=4.971$ & SIS (USA) & $=0.912$ & ICV (Poland) & $=6.630$ \\
\hline & ISI (Dubai, UAE & $=0.829$ & РИНЦ (Russia & $=0.126$ & PIF (India) & $=1.940$ \\
\hline & GIF (Australia) & $=0.564$ & ESJI (KZ) & $=8.716$ & IBI (India) & $=4.260$ \\
\hline & JIF & $=1.500$ & SJIF (Morocce & $=5.667$ & OAJI (USA) & $=0.350$ \\
\hline
\end{tabular}

35. Frambach, R. T., \& Schillewaert, N. (2002). Organizational innovation adoption: A multilevel framework of determinants and opportunities for future research. Journal of business research, 55(2), 163-176.

36. Cardoso, J., Sheth, A., Miller, J., Arnold, J., \& Kochut, K. (2004). Quality of service for workflows and web service processes. Journal of web semantics, 1(3), 281-308.

37. Gordon, S., \& Monideepa, T. (2007). How do a company's information technology competences influence its ability to innovate?, Journal of Enterprise Information Management, Vol. 20, Issue. 3; pg. 271.

38. Doz, Y. L. (1987). Technology partnerships between larger and smaller firms: Some critical issues. International Studies of Management \& Organization, 17(4), 31-57.

39. Jackson, S. (2011). Organizational culture and information systems adoption: A three perspective approach. Information and Organization, 21(2), 57-83.

40. Hendrickson, A. R. (2003). Human resource information systems: Backbone technology of contemporary human resources. Journal of Labor Research, 24(3), 381.

41. Boating (2007). "The Role of Human Resource Information Systems (HUMAN RESOURCE INFORMATION SYSTEMS ) in Strategic Human Resource Manage-ment (SHRM)," Master of Science Theses, Accounting Swedish School of Economics and Business Administra-tion, Palovartijantie.

42. Baird, L., \& Meshoulam, I. (1988). Managing two fits of strategic human resource management. Academy of Management review, 13(1), 116-128.

43. Buhler, P. (2002). Human resources management: All the information you need to manage your staff and meet your business objectives. Simon and Schuster.

44. Van de Vrande, V., De Jong, J. P., Vanhaverbeke, W., \& De Rochemont, M. (2009). Open innovation in SMEs: Trends, motives and management challenges. Technovation, 29(6-7), 423-437.

45. Beckers, A.M., \& Bsat, M.Z. (2002). A DSS classification model for research in human resource information systems. Information Systems Management, 19, 41-50.

46. Kavanagh, M. J., \& Johnson, R. D. (Eds.). (2017). Human resource information systems: Basics, applications, and future directions. Sage Publications.

47. Brown, D. (2002). E-HR: victim of unrealistic expectations. Canadian HR Reporter, 15, 1-6.

48. Endozo, A. N. (2019). Structuring the quadratic effect of motivation towards mental tasks performance among university students. Journal of theoretical and applied information.

49. Anakwe, U. P. (2002). Human resource management practices in Nigeria: challenges and insights. International Journal of Human Resource Management, 13(7), 1042-1059.

50. Oluyinka, S., \& Endozo, A. (2019). Factors Affecting Physical Activity Participation Among University Students. Journal of social science research, 14, 3161-3170.

51. Venkatesh, V., Davis, F., \& Morris, M. G. (2007). Dead or alive? The development, trajectory and future of technology adoption research. Journal of the association for information systems, 8(4), 1.

52. Davis, F. D. (1989). Perceived usefulness, perceived ease of use, and user acceptance of information technology. MIS quarterly, 319340.

53. Endozo, A., \& Solomon, O. (2019). Teachers' perceptions in enhancing low skilled students in higher institutions 2019 Journal ISJ Theoretical \& Applied Science, 2(70), 244-251. Doi: 10.15863/TAS.2019.02.70.21

54. Endozo, A.N., Oluyinka, S., \& Daenos, R.G. (2019). Teachers' Experiences towards Usage of Learning Management System: CANVAS ICETC 2019: Proceedings of the 2019 11th International Conference on Education Technology and ComputersOctober 2019 ,Pages 91-95. https://doi.org/10.1145/3369255.3369257

55. Solomon, O., Endozo, A., \& Daenos, R.G. (2019). Impediments to Acceptance of Online Learning in Two Developing International Locations ICETC 2019: Proceedings of the 2019 11th International Conference on Education Technology and ComputersOctober 2019 Pages 127-131. https://doi.org/10.1145/3369255.3369256

56. Ayodele, S. O., Oga, O. E., Bundot, Y. G., \& Ogbari, M. E. (2016, October). Role of power supply towards e-learning acceptance: VBSEMAMOS. In 2016 6th International Conference on Information Communication and Management (ICICM) (pp. 151-155). IEEE.

57. Solomon, O., Shamsuddin, A., Wahab, E., Musibau A. A., \& Enegbuma, W. I. (2013). A study of electronic commerce adoption factors in Nigeria. International Journal of Information Systems and Change Management, 6(4).

58. Oluyinka, S. A., Endozo, A. N., \& Calma, R. R. (2018, October). A study on the acceptance of internet banking. In Proceedings of the 10th International Conference on Education Technology and Computers (pp. 374-378). 